\title{
Quantitative Determination of
}

\section{Cytoplasmic Membrane Invaginations in Phototrophically Growing Rhodospirillum rubrum. A Freeze-etch Study}

\author{
By J. R. GOLECKI AND J. OELZE \\ Lehrstuhl für Mikrobiologie, Universität Freiburg, Biologie II, D-78 Freiburg, Germany
}

(Received 23 September 1974; revised 6 January 1975)

SUMMARY

Rhodospirillum rubrum was investigated electronmicroscopically after freezeetching. Indentations on the convex faces of cytoplasmic membranes and protuberances on the concave faces were interpreted to represent sites of invaginations for intracytoplasmic membranes. The number of such invagination sites $/ \mu \mathrm{m}^{2}$ of membrane face increased as the cellular bacteriochlorophyll content increased, but no defined proportionality between these parameters could be established.

\section{INTRODUCTION}

Anaerobically, light (i.e. phototrophically) grown Rhodospirillum rubrum, like other members of the phototrophic bacteria, contains intracytoplasmic membranes which are sites for photochemical electron transport and coupled reactions (Frenkel, 1970). The cytoplasmic membrane, on the other hand, is a site for respiratory electron transport reactions in phototrophic as well as in aerobically, dark (i.e. chemotrophically) grown cells (Oelze \& Drews, 1972). Usually, intracytoplasmic membranes are not present in chemotrophic cells. Upon transfer of chemotrophic cultures to phototrophic conditions, however, intracytoplasmic membranes are formed (Lascelles, I968; Oelze \& Drews, I972). Electron micrographs of thin sections revealed connexions between cytoplasmic and intracytoplasmic membranes (Drews \& Giesbrecht, I963; Boatman, I964; Hickman \& Frenkel, I965). This finding, and results obtained from experiments with isolated membrane fractions, have led to the hypothesis that intracytoplasmic membranes are formed by invagination of the cytoplasmic membrane.

The amount of intracytoplasmic membrane is variable, depending on culture conditions (Cohen-Bazire \& Kunisawa, 1963; Holt \& Marr, 1965; Hickman \& Frenkel, 1965). This raises the question whether an extension of the intracytoplasmic membrane system is confined to existing intracytoplasmic membranes only, or whether cytoplasmic membranes also participate by forming new invaginations. While in the first case, as suggested by Kosakowski \& Kaplan (1974), the number of invaginations should reach a constant value after a relatively short initial period of adaptation to phototrophy, the number should be expected to increase further in the second case.

We have attempted to answer these questions by electron microscopic investigations of freeze-etched specimens of $R$. rubrum. 

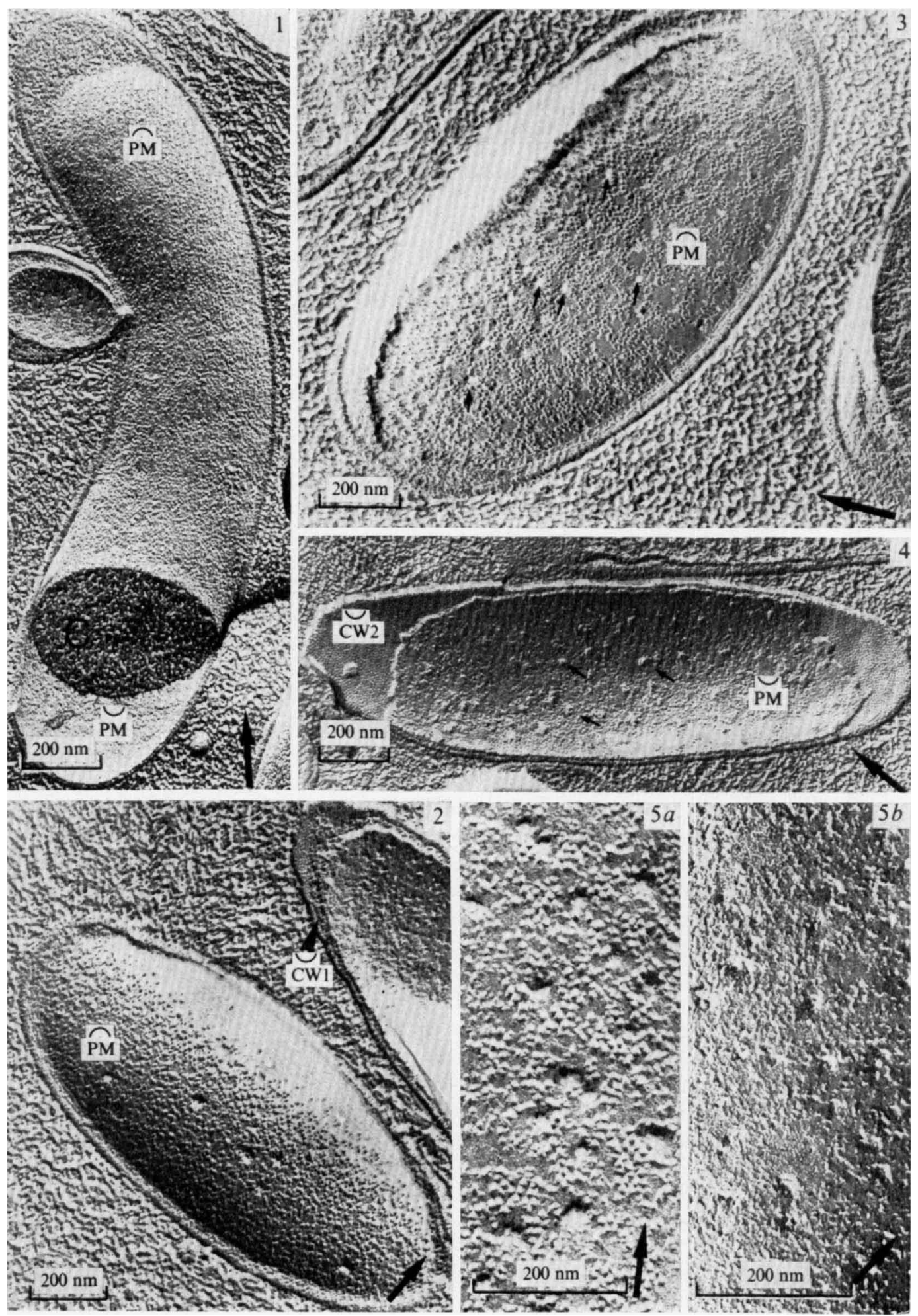


\section{METHODS}

Cultivation of bacteria. Rhodospirillum rubrum, strain FR I, was cultivated chemotrophically as described by Oelze et al. (I969). To study the formation of cytoplasmic membrane invaginations, chemotrophically grown cultures were inoculated into fresh culture medium and cultivated under anaerobiosis in the light. Light intensity, measured approximately at the centre of the culture vessel, was $800 \mathrm{ft}$-candle at the beginning of the experiment. After about $25 \mathrm{~h}$ the culture growth reached the stationary phase. Bacteria in $50 \mathrm{ml}$ of this culture were separated by centrifugation, resuspended in the same volume of fresh medium, and incubated under constant stirring anaerobically in the light. This procedure was repeated three times within $40 \mathrm{~h}$. Thus, it was possible to obtain a bacteriochlorophyll content about twice as high as that measurable at the beginning of the stationary phase.

Quantitative estimations. Protein was determined by the method of Lowry et al. (I95I). The bacteriochlorophyll content was measured in methanol by using the specific extinction coefficient recommended by Smith \& Benitez (I955).

Electron microscopy. Bacterial samples were separated from the culture medium by centrifugation and incubated stepwise with glycerol to a final concentration of $30 \%(\mathrm{v} / \mathrm{v})$. Specimens were mounted on $3 \mathrm{~mm}$ gold discs, frozen in Freon 22, and plunged into liquid nitrogen. Freeze-etching was performed in a Balzers unit BA $360 \mathrm{M}$ according to Moor \& Mühlethaler (1963). Etching time was I min at $-100{ }^{\circ} \mathrm{C}$. Replicas were examined in a Siemens Elmiskop IA at $80 \mathrm{kV}$.

Quantitative determination on electron micrographs. To count the invaginations of the cytoplasmic membrane $/ \mu \mathrm{m}^{2}$, the areas of exposed membrane fracture faces were determined by weighing copies on transparent paper of these areas. In each experiment at least 20 determinations were performed.

\section{RESULTS AND DISCUSSION}

Freeze-etching of chemotrophically grown $R$. rubrum exposed four fracture faces of the cell envelope which resembled those of other Gram-negative micro-organisms (van Gool \& Nanninga, 1971; Gilleland et al. 1973). Besides the complementary convex and concave faces of fracture planes in the outer cell wall ( $\widetilde{C W}_{2}$, Fig. 4) there were the convex and concave faces in the cytoplasmic membrane ( $\widehat{P M}$ and $\mathrm{PM}$, respectively). In some cases there was a further layer $\left(\widetilde{\mathrm{CW}}_{\mathrm{I}}\right)$ observable between the $\mathrm{CW}_{2}$ layer and concave fracture

The arrows in the lower right-hand corners indicate the direction of shadowing. $\widehat{P M}$ and $\breve{P M}$, convex and concave fracture faces of cytoplasmic membrane, respectively. $\mathrm{CW}_{2}$, concave fracture face of wall; $\breve{C W}_{\mathrm{I}}$, concave fracture face of wall (intermediate layer); $\mathrm{C}$, cytoplasm.

Fig. I. Fracture face of $R$. rubrum grown chemotrophically, exposing $\widehat{P M}$. No indentations are detectable in the cytoplasmic membrane; accordingly, no intracytoplasmic membrane vesicles are visible.

Fig. 2. $\widehat{\mathrm{PM}}$ of phototrophically grown $R$. rubrum with low bacteriochlorophyll content $(\mathrm{I} \cdot 7 \mu \mathrm{g} / \mathrm{mg}$ cell protein). Only a few indentations are detectable. A middle layer (CWI) is visible between the concave fracture faces of cell wall $\left(\mathrm{CW}_{2}\right)$ and the cytoplasmic membrane.

Fig. 3. Convex fracture face of phototrophically grown $R$. rubrum exposing indentations (indicated by small arrows) of the cytoplasmic membrane. Cells contained $20 \cdot 6 \mu \mathrm{g}$ bacteriochlorophyll $/ \mathrm{mg}$ cell protein (see also Table 1 ).

Fig. 4. The corresponding concave fracture face of the cytoplasmic membrane PัM with numerous protuberances (indicated by small arrows).

Fig. 5. Fracture faces of the cytoplasmic membrane exhibiting indentations ( $a$ ) and protuberances (b) at higher magnification. 


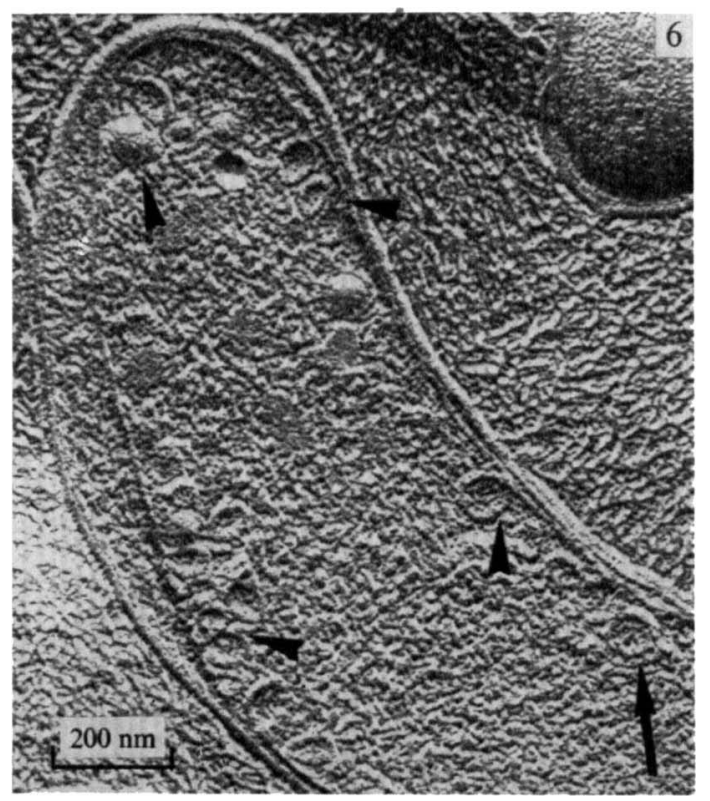

Fig. 6. Cross-fractured cell of a phototrophically grown $R$. rubrum, exposing numerous intracytoplasmic vesicles (indicated by short arrows) underneath the cell envelope. The longer arrow indicates the direction of shadowing.

plane of the cytoplasmic membrane $(\widetilde{\mathrm{CW}}$ I in Fig. 2$)$. The convex fracture plane $(\widehat{\mathrm{PM}})$ of the cytoplasmic membrane was densely covered with particles of diameter 6.0 to $8.0 \mathrm{~nm}$ (Fig. I). The corresponding concave plane $(\widetilde{\mathrm{PM}})$ showed a sparse distribution of particles of different size, as well as some holes.

Fracture planes on cytoplasmic membranes of phototrophically grown $R$. rubrum reveaied the presence of substructures in addition to those demonstrated in chemotrophically grown cells. While on convex fracture faces $(\overparen{\mathrm{PM}})$ there were numerous indentations (Figs. 3, 5a) concave fracture faces exhibited numerous protuberances (Figs. $4,5 b$ ). The indentations and protuberances probably represented sites of invaginations for intracytoplasmic membranes. Therefore such substructures on fracture planes should provide a quantitative estimate of membrane invaginations. This suggestion was based on the following observations. Diameters of the protuberances and indentations, as well as diameters of membrane invagination sites demonstrated in thin sections $(20$ to $30 \mathrm{~nm})$, were within the same order of magnitude (Drews \& Giesbrecht, 1963; Boatman, 1964; Hickman \& Frenkel, 1965). Also, protuberances and indentations were not detectable in chemotrophic cells and were present only when intracytoplasmic membranes could be demonstrated in the crossfractured cytoplasm (Fig. 6).

To study the development of intracytoplasmic membranes in cells of $R$. rubrum on the basis of invaginations, we transferred cells from aerobic dark (i.e. chemotrophic) to anaerobic light (i.e. phototrophic) conditions. At defined times after transfer to the light, samples were withdrawn for determination of the bacteriochlorophyll contents and for the preparation of freeze-etch specimens.

While electron micrographs of thin sections could reveal only a very few of the total connexions between cytoplasmic and intracytoplasmic membranes per cell, freeze-etching provided an elegant means to detect all the invaginations per unit area of membrane surface. 
Table I. Bacteriochlorophyll content and number of cytoplasmic membrane invaginations in $R$. rubrum

$\begin{array}{lcc}\text { Culture conditions* } & \begin{array}{c}\text { Bacteriochlorophyll } \\ (\mu \mathrm{g} / \mathrm{mg} \text { protein })\end{array} & \begin{array}{c}\text { No. of invaginations/ } \\ \mu \mathrm{m}^{2} \text { membrane } \\ \text { surfacet }\end{array} \\ \text { Aerobic, dark } & \text { ND } & 0 \\ \text { Anaerobic, light }(3 \mathrm{~h}) & 0 \cdot 6 & 0 \\ \text { Anaerobic, light }(6 \mathrm{~h}) & 1 \cdot 7 & \mathrm{I} 6 \cdot 7 \pm 8 \cdot 2 \\ \text { Anaerobic, light }(\mathrm{I} 2 \mathrm{~h}) & 5 \cdot 7 & 37 \cdot 3 \pm \mathrm{II} \cdot 0 \\ \text { Anaerobic, light }(23 \mathrm{~h}) & 20 \cdot 6 & 52 \cdot 4 \pm 9 \cdot 2 \\ \text { Anaerobic, light }(60 \mathrm{~h}) & 45.4 & 63 \cdot \mathrm{I} \pm 6 \cdot 3\end{array}$

ND, Not detectable.

* The times after transfer from chemotrophic to phototrophic conditions are given in parentheses.

$\dagger$ Significance of the values is based on a $99 \%$ confidence level.

Figs. 2, 3, 4 and 5 demonstrate that the number of indentations and protuberances of the cytoplasmic membrane fracture faces increased as the bacteriochlorophyll content of the cells increased. The irregular mode of occurrence of invaginations suggested a random occurrence rather than a fixed pattern. This was observed especially during the early phases of adaptation of chemotrophically grown cells to phototrophic conditions (Fig. 2).

The quantitative data (Table I) indicate that shortly after onset of phototrophy, bacteriochlorophyll was synthesized without any significant formation of invaginations (first phase). These findings answered the question, whether during the initial phases of adaptation, bacteriochlorophyll was incorporated into cytoplasmic membranes, or into a few intracytoplasmic membranes which could not be detected before because they did not happen to be in the plane of the section. As the bacteriochlorophyll content increased, in a second phase, invaginations of the cytoplasmic membrane occurred and increased in number. However, proportionality between the rates of bacteriochlorophyll and invagination formation could not be established. This could be explained by Oelze \& Drews' (1972) hypothesis on intracytoplasmic membrane formation: that the photosynthetic apparatus could be incorporated into the cytoplasmic membrane immediately after transition to phototrophic conditions; it could not be specified whether incorporation was patchy or homogeneous, but in either case there would result a significant, if slight, differentiation of the cytoplasmic membrane. In agreement with this hypothesis, no indentations or protuberances of the cytoplasmic membrane fracture faces could be shown when cells contained very low levels of bacteriochlorophyll (Table I). The hypothesis furthermore proposed that, at increasing pigment levels, cytoplasmic membranes form invaginations which elongate and differentiate simultaneously by preferential incorporation of the photosynthetic apparatus. Finally, intracytoplasmic membranes could be developed in a fixed ratio of different constituents with a residual proportion (about $5 \%$ ) of cytoplasmic membrane proteins (Oelze et al. 1969; Oelze \& Drews, 1972). Concerning the formation of bacteriochlorophyll and cytoplasmic membrane invaginations, it followed that most of the pigment was deposited in intracytoplasmic membranes, though this process might not have been correlated with the occurrence of new invaginations. Nevertheless, the significantly increasing number of invaginations demonstrated by the Figures and Table indicate that the cytoplasmic membrane was involved, even in more advanced stages, in the continuous proliferation of new intracytoplasmic membranes. Thus we conclude that an extension of the intracytoplasmic membrane system is facilitated simultaneously by elongation of invaginations and by an increase in the number of invaginations. 
The results of Gorchein, Neuberger \& Tait (1968) and Gibson, Segen \& Niederman (1972) for Rhodopseudomonas spheroides agree essentially with our results for $R$. rubrum. Huang \& Kaplan (1973) and Kosakowski \& Kaplan (1974), on the other hand, have proposed a different method for intracytoplasmic membrane formation in Rhodopseudomonas spheroides: the cytoplasmic membrane serves initially only as a kind of condensation site for the constituents of one single intracytoplasmic membrane per cell, and any further development of intracytoplasmic membranes results from changes in the length of this intracytoplasmic membrane. This concept is incompatible with our data, at least as obtained for R. rubrum.

We thank H. Bischoff and D. Riedel for conscientious technical assistance. This research was supported by SFB 46 and Deutsche Forschungsgemeinschaft grant Go 264/I.

\section{REFERENCES}

Boatman, E. S. (1964). Observations on the fine structure of spheroplasts of Rhodospirillum rubrum. Journal of Cell Biology 20, 297-3I I.

COHEn-Bazire, G. \& KUnisawa, R. (1963). The fine structure of Rhodospirillum rubrum. Journal of Cell Biology 16, 40I-419.

Drews, G. \& GiesBReChT, G. (I963). Zur Morphogenese der Bakterien-'Chromatophoren' (-Thylakoide) und zur Synthese des Bakteriochlorophylls bei Rhodopseudomonas spheroides und Rhodospirillum rubrum. Zentralblatt für Bakteriologie, Parasitenkunde, Infektionskrankheiten und Hygiene (Orig., Abteilung I) 190, 508-535.

FRENKEL, A. W. (I970). Multiplicity of electron transport reactions in bacterial photosynthesis. Biological Reviews 45, 569-6I 6.

Gibson, K. D., SEgen, B. J. \& Niederman, R. A. (1972). Membranes of Rhodopseudomonas spheroides. JI. Precursor-product relations in anaerobically growing cells. Archives of Biochemistry and Biophysics I52, $56 \mathrm{I}-568$.

Gilleland, H. E., Stinnetr, J. D., Roth, I. D. \& Eagon, R. G. (1973). Freeze-etch study of Pseudomonas aeruginosa: localization within the cell wall of an ethylenediamine tetraacetate-extractable component. Journal of Bacteriology $\mathbf{1 3}$, 417-432.

van Gool, A. P. \& NANnINGA, N. (I97I). Fracture faces in the cell envelope of Escherichia coli. Journal of Bacteriology 108, 474-48I.

GorChein, A., Neuberger, A. \& TAIt, G. H. (1968). Metabolic turnover of the lipids of Rhodopseudomonas spheroides. Proceedings of the Royal Society B I70, $3 \mathrm{II}-3 \mathrm{I} 8$.

HickmAn, D. D. \& Frenkel, A. W. (I965). Observations on the structure of Rhodospirillum molischianum. Journal of Cell Biology 25, 261-278.

Holt, S. C. \& MARR, A. G. (1965). Effect of light intensity on the formation of intracytoplasmic membrane in Rhodospirillum rubrum. Journal of Bacteriology 89, I42 I-I 429.

HUANG, J. W. \& KAPLAN, S. (1973). Membrane proteins of Rhodopseudomonas spheroides. IV. Characterization of chromatophore proteins. Biochimica et biophysica acta 307, 31 7-33I.

Kosakowski, M. H. \& KaPLAN, S. (1974). Topology and growth of the intracytoplasmic membrane system of Rhodopseudomonas spheroides: protein, chlorophyll and phospholipid insertion into steady state anaerobic cells. Journal of Bacteriology I18, I $144-1157$.

Lascelles, J. (I968). The bacterial photosynthetic apparatus. In Advances in Microbial Physiology, vol. 2, pp. I-42. Edited by A. H. Rose and J. F. Wilkinson. New York and London: Academic Press.

Lowry, O. H., Rosebrough, N. J., Farr, A. L. \& Randall, R. J. (195I). Protein measurement with the Folin phenol reagent. Journal of Biological Chemistry 193, 265-275.

Moor, H. \& Mühlethaler, K. (1963). Fine structure in frozen etched yeast cells. Journal of Cell Biology I7, 609-628.

Oelze, J. \& Drews, G. (1972). Membranes of photosynthetic bacteria. Biochimica et biophysica acta $\mathbf{2 6 5}$, 209-239.

Oelze, J., Biedermann, M., Freund-Mölbert, E. \& Drews, G. (1969). Bacteriochlorophyllgehalt und Proteinmuster der Thylakoide von Rhodospirillum rubrum während der Morphogenese des Photosynthese-Apparates. Archiv für Mikrobiologie 66, I 54-165.

Smith, J. H. C. \& BeniteZ, A. (1955). Chlorophylls. In Moderne Methoden der Pflanzenanalyse, pp. 142-195. Edited by K. Paech and M. V. Tracey. Berlin, Heidelberg: Springer Verlag. 